\title{
TITLE:
}

\section{Embedding Spheres and Balls in Codimension $\leqq 2$ (Abstract_要旨)}

$\operatorname{AUTHOR}(S):$

Kato, Mitsuyoshi

\section{CITATION:}

Kato, Mitsuyoshi. Embedding Spheres and Balls in Codimension $\leqq 2$. 京 都大学, 1971, 理学博士

ISSUE DATE:

1971-07-23

URL:

http://hdl.handle.net/2433/213722

RIGHT: 


\section{【 48 】}

氏 名

$\begin{array}{lll}\text { 加 } & \text { 藤 } & \text { 吉口 } \\ \text { 吉し }\end{array}$

学位の種 類

理学博士

学位記 番号

論 理 博 第 356 号

学位授与の日付

昭 和 46 年 7 月 23 日

学位授与の要件

学位規則第 5 条第 2 項該当

学位論文題目

\section{Embedding Spheres and Balls in Codimension $\leqq 2$}

(余次元 2 以下の球面と球体の埋蔵)

論文調査委員教授戸田宏教授小松醇 郎教授島田信夫

\section{論文内容の要旨}

申請者加藤十吉はこの論文に扣いて余次元 2 以下の場合の球面扣よび球体の埋めこみに関する各種の条 件をくわしく研究し, それに基づいて余次元 2 以下の組み合わせ多様体の埋めこみ問題に一つの解答を与 えた。

$\mathrm{m}$ 次元多様体 $\mathrm{M}$ を $\mathrm{q}$ 次元多様体 $\mathrm{Q}$ の中へ埋めこみうるための条件括よび埋めこみが同位を法として一 意的であるための条件を多様体の次元 $\mathrm{m}, \mathrm{q}$ 牤よびそれらの連結性を用いて表わすことが，多様体の埋め こみ問題の一般な形である。多様体が微分可能多様体の場合には A. Haefliger 等によって, 余次元 $\mathrm{q}-\mathrm{m}$ $\geqq 3$ の組み合わせ多様の場合には Penrose-Whitehead-Zeeman 特よび Irwin 等によって，埋めこみ問 題の一応の解決を見たが, 余次元 $q-m \leqq 2$ の組み合わせ多様体の場合には, 組み合わせ多様体の研究に 括ける強力な手段である吸いこみ定理 (engulfing theorem) が余次元 $q-m \leqq 2$ の場合には成立しない ことが埋めこみ問題の解決に执ける障害であった。

本論文に怙いて申請者は上の Irwin らの定理が $\mathrm{m} \geqq 5$ のとき, 余次元 $\mathrm{q}-\mathrm{m} \leqq 2$ でもなりたつことを 示して，組み合わせ多様体の埋めこみ間題の解答を与えることに成功した。申請者はこのために，まず $(\mathrm{q}-3)$ 一連結な $\mathrm{q}$ 次元組み合わせ多様体 $(\mathrm{q} \geqq 5)$ の $(\mathrm{q}-1)$ 一次元および $(\mathrm{q}-2)$ 一次元ホモロジー類 が，埋めこめられた球面または球体で実現されることを示した。この準備のもとに，Irwin の定理の余次 元 $\leqq 2$ の場合が証明され，その結果は次のようにのべられる。

境界をるった組み合わせ多様体の写像 $\varphi:(\mathrm{M}, \partial \mathrm{M}) \rightarrow(\mathrm{Q}, \partial \mathrm{Q})$ について次の条件が満されているとす る。 $\varphi$ は $\partial \mathrm{M}$ 上では埋めこみであ $り, \varphi^{-1}(\partial \mathrm{Q})=\partial \mathrm{M}$, 多様体の次元 $\mathrm{m}, \mathrm{q}$ について $\mathrm{m} \geqq 5, \mathrm{q}-\mathrm{m} \leqq 2$, さらに $\mathrm{M}$ は $(2 \mathrm{~m}-\mathrm{q})$ 一連結, $\mathrm{Q}$ は $(2 \mathrm{~m}-\mathrm{q}+1)$ 一連結であるとする。そのとき $\varphi$ は $\partial \mathrm{M}$ を固定し たホモトピーによって一つの埋めこみ $f: M \rightarrow Q$ に变形される。さらに $\varphi$ が $\partial \mathrm{M}$ 上で局所平坦の場合 は, “ $\mathrm{q}=\mathrm{m}+2$ =奇数ならば $\mathrm{f}$ は局所平坦にとれる”。

申請者の証明の要点は $(q-3)$ 一連結 $\mathbf{q}$ 次元多様体を, 微分位相幾何学の主要手段であるハンドル分解 
によって可縮な多様体に変形し，そこへ吸いこみ定理を適用することによって，Irwin の定理の球体の場 合を示し，次にハンドル分解の逆操作を検討しながら一般の場合に到達する。

このように, 組み合わせ位相幾何学では従来使われなかったハンドル分解を積極的に導入し, その上に 可縮多様体の境界の framed link に精密な検討を加えることによって埋めこみ問題の解決に成功した。 な陉局所平坦性は応用上重要であるので，これについても $\mathrm{q}=\mathrm{m}+2=$ 偶数の場合を除いて局所平坦にと れることを証明し, $\mathrm{q}=\mathrm{m}+2=$ 偶数の場合には，反例のあることを示している。

\section{論文審 査の結 果の要旨}

多様体の埋めこみの問題はそれ自身注目すべきことである上に多様体の性質を研究するためには不可欠 の問題である。埋めこみの理論は, 取扱う多様体が微分可能多様体であるか組み合わせ多様体であるかに よって様相が大いに異なっている。

微分可能多様体の場合は, 1930年代の $\mathrm{H}$. Whitney の基礎的研究にはじまり, 近年 A. Haefliger 等 によって, 埋めこみの理論が整理統合され，大きな発展をとげ， $\mathrm{m}$ 次元多様体 $\mathrm{M}$ を次元多様体 $\mathrm{Q}$ の中 へ埋めこみ得るための条件颃よでその埋めこみが同位の意味で一意的であるための条件が，2つの多様体 の次元 $\mathrm{m}, \mathrm{q}$ 打よびそれらの連結性をもって表現された。

組み合わせ多様体の埋めこみに関しては，これと類似の理論が Penrose-Whitehead-Zeeman 打よび Irwin によって作られたが，この場合の基本的手段である吸いこみ定理 (engulfing theorem) に余次元 $\mathrm{q}-\mathrm{m}$ が 3 以上でしかなりたたないという制約があるため，余次元 2 以下の場合は未解決の問題として残 されていた。

申請者加藤十吉は，主論文に抬いて，上の Irwin らの定理が $\mathrm{m} \geqq 5$ のとき余次元 $\mathrm{q}-\mathrm{m}$ が 2 以下の 場合にもなりたつことを示して, 組み合わせ多様体の埋めこみ問題の解決に成功している。このため申請 者は最も基本的である球面执よび胞体の埋めこみのための条件をくわしくしらべ，その結果の上に立って 一般の組み合わせ多様体の場合を解決している。このとき用いられる手段は上記の吸いこみ定理の外に微 分位相幾何学に扣いてよく用いられる球面改変扣よびハンドル分解の理論であり，これらを縦横に駆使し て問題を解決したことは, 組久合わせ位相幾何学和よび微分位相幾何学双方に広い知識と識見を有する申 請者によって初めてなし得られたものと考えられる。

参考論文 2 編はともに組み合わせ位相幾何学に関するもので, 申請者がこの方面の優れた研究者である ことを示している。

よって，本論文は理学博士の学位論文として価値あるものと認める。 